\title{
Apolipoprotein L1
}

National Cancer Institute

\section{Source}

National Cancer Institute. Apolipoprotein L1. NCI Thesaurus. Code C138153.

Apolipoprotein L1 (398 aa, $44 \mathrm{kDa}$ ) is encoded by the human APOL1 gene. This protein is involved in lipid transport and metabolism. 